\title{
Haematological alterations of Leporinus macrocephalus (Osteichtyes: Anostomidae) naturally infected by Goezia leporini (Nematoda: Anisakidae) in fish pond
}

[Alterações hematológicas em Leporinus macrocephalus (Osteichtyes: Anostomidae) infectado naturalmente por Goezia leporini (Nematoda: Anisakidae) em viveiro de piscicultura]

\author{
M.L. Martins ${ }^{1}$, M. Tavares-Dias ${ }^{2}$, R.Y.Fujimoto ${ }^{2}$, E.M. Onaka ${ }^{2}$, D.T. Nomura ${ }^{2}$ \\ ${ }^{1}$ Departamento de Aqüicultura - CCA - UFSC \\ Caixa Postal 476, Itacorubi \\ 88040-900 - Florianópolis, SC \\ ${ }^{2}$ Centro de Aqüicultura - UNESP - Jaboticabal, SP
}

\begin{abstract}
The effect of Goezia leporini Martins \& Yoshitoshi, 2003 (Nematoda: Anisakidae) infection on the haematological characteristics of cultivated Leporinus macrocephalus (Osteichthyes:Anostomidae) was studied. Paleness of gills, kidneys, liver and heart, black spots on the kidney and accumulation of fluid in the visceral cavity, stomach and intestines were observed. Gall bladder content had pale and translucent aspect. Strong and slight positive correlations between number of nematodes and fish weight were estimated within the $0-100 \mathrm{~g}$ and 100-200g fish weight group, respectively. Blood smears from infected fish showed variation in erythrocyte size (anisocytosis) and shape (poikilocytosis), and also dividing erythrocytes. No significant alteration $(\mathrm{P}>0.05)$ was shown as to erythrocyte, leukocyte count, haemoglobin concentration and thrombocyte and monocyte percentage. Parasite infection provoked significant reduction $(\mathrm{P}<0.05)$ in hematocrit, mean corpuscular volume, mean corpuscular haemoglobin concentration and lymphocyte percentage. On the other hand, significant increase $(\mathrm{P}<0.05)$ in neutrophil and eosinophil percentage in circulating blood of infected fish was observed. This is the first report regarding haematology of nematode infected freshwater cultivated fish in Brazil.
\end{abstract}

Keywords: Brazilian fish, piauçu, Leporinus macrocephalus, Nematoda, Goezia leporini, haematology

\section{RESUMO}

Estudou-se efeito da infecção por Goezia leporini Martins \& Yoshitoshi, 2003 (Nematoda: Anisakidae) sobre as características hematológicas de Leporinus macrocephalus (Osteichthyes:Anostomidae) cultivado. Palidez das brânquias, rins, fígado e coração, pontos negros nos rins e acúmulo de líquido na cavidade visceral, estômago e intestinos foram observados. O conteúdo da vesícula biliar tinha aparência pálida e translúcida. Observaram-se alta e moderada correlações positivas entre número de nematóides e peso do peixe estimadas dentro dos grupos de peixe de 0-100g e 100-200g, respectivamente. As extensões sangüineas revelaram variações no tamanho (anisocitose) e forma (poiquilocitose) dos eritrócitos, bem como eritrócitos em divisão. Não houve alteração $(P>0,05)$ na contagem total de eritrócitos, de leucócitos, na taxa de hemoglobina e nos percentuais de trombócitos e monócitos. A infecção provocou redução $(P<0,05)$ no percentual de hematócrito, no volume corpuscular médio, na concentração de hemoglobina corpuscular média e no percentual de linfócitos, e aumento $(P<0,05)$ no percentual de neutrófilos e eosinófilos no sangue circulante de peixes infectados. Este é o primeiro relato no Brasil que relaciona hematologia e infecção por nematóides em peixes cultivados.

Palavras-chave: peixe brasileiro, piauçu, Leporinus macrocephalus, Nematoda, Goezia leporini, hematologia

Recebido para publicação em 18 de setembro de 2003

Recebido para publicação, após modificações, em 1 de março de 2004

E-mail: mlaterca@cca.ufsc.br 


\section{INTRODUCTION}

With the advancement of reproduction technology, as well as in larval and fry culture in the last decades, some important fish species have been studied for cultivation in tropical regions (Zaniboni-Filho, 1997). Leporinus macrocephalus is one of the most cultivated freshwater fish in Brazil, used to supply fish farm and sportive fishing facilities. With intensification of Brazilian aquaculture, fish mortality caused by infectious and parasitic agents were frequently observed (Martins et al., 2002). In cultivated fish of the United States, parasitic diseases caused an economic loss estimated in US\$11.5 million in 1989 (Klesius and Rogers, 1995). In Brazil, an estimation of economic losses caused by infectious and parasitic diseases in cultivated fish does not exist. The damage caused on the host depends on parasite species, type of spoliation of host tissue, number of parasites and the health status of the host (Tavares-Dias et al., 1999b). Parasites may often cause anemia, which is characterized by reduced haemoglobin concentration and reduced hematocrit and erythrocyte number.

Studies on haematological alterations of cultivated Brazilian fish has been recently applied to Cyprinus carpio (Ranzani-Paiva et al., 1987) and Piaractus mesopotamicus (TavaresDias et al., 1999a) infected with Argulus sp.; Mugil platanus infected with Trypanosoma, Hemogregarina, Trichodina, Monogenoidea, copepods and Hirudinea (Ranzani-Paiva et al., 1997); P. mesopotamicus and L. macrocephalus infected with Monogenoidea, Ichthyophthirius multifiliis, Trichodina sp., Piscinoodinium pillulare and Lernaea cyprinacea (Tavares-Dias et al., 1999b) and Oreochromis niloticus infected with I. multifiliis (Tavares-Dias et al., 2002).

The aim of this study was to evaluate haematological alterations of L. macrocephalus infected with anisakid nematodes.

\section{MATERIAL AND METHODS}

Thirty-two specimens of L. macrocephalus Garavello \& Britski, 1988 were captured using fishing rod at a fish farm situated in Batatais, São Paulo State, Brazil, where they were cultivated in $300 \mathrm{~m}^{2}$ area ponds and fed with commercial diet.
The fish were taken to the Laboratory of Fish Pathology at the Research Center for Animal Health (CPPAR-UNESP), and then kept for seven days for haematological and parasitological testing. The fishes were divided into three groups by weight: 0 to $100 \mathrm{~g}(\mathrm{n}=16)$, 101 to $200 \mathrm{~g}(\mathrm{n}=10)$ and 201 to $600 \mathrm{~g}(\mathrm{n}=6)$.

Water quality was analyzed at the moment the fishes were captured. Water $\mathrm{pH}$ values of 6.7-7.3 were found using a "Corning" $\mathrm{pH}-$ meter. The electric conductivity, measured by "Corning" conductivimeter, was $5.0-20.0 \mu \mathrm{S} / \mathrm{cm}$. Dissolved oxygen was $7.0-7.6 \mathrm{mg} / 1$, measured with a YSIMod.50 oxymeter and water temperature was $18.0-19.0^{\circ} \mathrm{C}$, measured with a mercury bulb thermometer.

After weighting and measuring, captured fish were immersed in benzocaine solution $1 \mathrm{~g} / 10 \mathrm{l}$ water for deep sedation until death. All fishes were then checked for tissue alteration and collection of parasites. Body mucus and pieces of gills, kidney, liver, spleen and heart with a drop of a $0.65 \%$ saline solution were compressed between a glass and glass cover slip for microscopic observation. Stomach and intestines were observed in a Petri dish containing saline solution. Parasite prevalence was calculated according to Bush et al. (1997).

Blood was withdrawn $(0.5 \mathrm{ml})$ from the fishes' caudal vein into a syringe containing a drop of a $10 \%$ EDTA solution. Blood samples were evaluated for haemoglobin concentration by the Collier method (Collier, 1944), hematocrit according to Goldenfarb et al. (1971), total erythrocytes count using a Neubauer haemocytometer, mean corpuscular haemoglobin concentration (MCHC) and mean corpuscular volume (MCV) according to Wintrobe (1934). For differential count of defence blood cells (leukocyte and thrombocyte), air-dried blood smears were prepared using the Rosenfeld method (Rosenfeld, 1947) in which a hundred cells were counted for establishment of each cell percent. The total count of leucocytes was performed with a Neubauer haemocytometer after blood dilution with a $0.65 \%$ sodium chloride solution containing $1 \%$ gentian violet and neutral red.

Analyses of variance for haematological values were performed and difference between infected 
and uninfected groups was F tested. Single correlation between fish weight and parasite number was estimated.

\section{RESULTS}

A total of 21 fishes had nematodes in the stomach (65\% prevalence). They were identified as being Goezia leporini Martins \& Yoshitoshi, 2003 (Nematoda:Anisakidae), a cylindrical stout nematode of a white-yellowish colour (Martins and Yoshitoshi, 2003). Females were larger than males and body cuticle provided distinct transverse striations and cuticle spines. Males were $20.31 \mathrm{~mm}$ (13.57-34.08) length and $0.70 \mathrm{~mm} \quad(0.45-1.06)$ width, and females $27.02 \mathrm{~mm} \quad(20.31-32.65 \mathrm{~m})$ length and $0.81 \mathrm{~mm}(0.31-1.12)$ width. Some of the parasites perforated the stomach wall and part of their bodies was seen in the visceral cavity. Fish examination revealed paleness of gills, kidney, liver, heart and gall bladder contents. In several cases, the kidney had small black spots on their surface. Fluid accumulation in the visceral cavity, stomach and intestines was also observed in infected fish. A strong positive correlation $(\mathrm{r}=0.78)$ between number of parasites and fish weight within the $0-100$ g group (Fig. 1) was observed. A slight positive correlation $(\mathrm{r}=0.67)$ between number of nematodes and fish weight within the $100-200 \mathrm{~g}$ group was also found. A few numbers of Monogenoidea (Dactylogyridae:Ancyrocephalinae) parasites were observed in the examined fishes' gills.

During collection, fish blood was cleared colour and was more fluid than normal in the infected fish. Haematological values such as erythrocyte and leukocyte counts and percentage of white cells in blood from infected and healthy fish are showed in Table 1. It was verified that erythrocyte and leukocyte counts, haemoglobin concentration, thrombocyte and monocyte percentage in infected fish were not different $(\mathrm{P}>0.05)$ when compared to healthy fish. However, parasitism was found to be associated with hematocrit reduction $(\mathrm{P}<0.05)$. MCV, MCHC and lymphocyte percentage were also significantly reduced. In addition, parasite infection apparently caused neutrophilia and eosinophilia in infected fish.

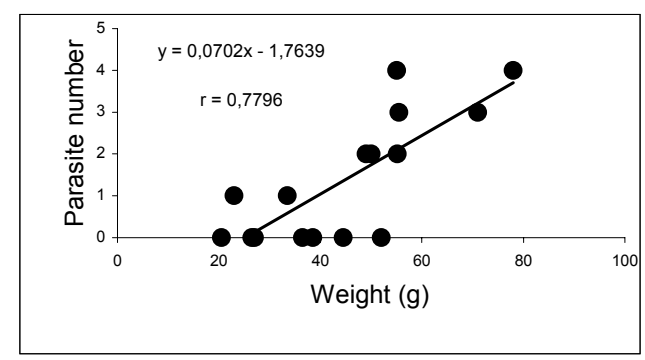

Figure 1. Correlation between parasite number and weight of Leporinus macrocephalus infected by Goezia leporini.

A great number of erythrocytes of various shapes (poikilocytosis) and size (anisocytosis) were observed in the blood smears from fish infected with $G$. leporini. Dividing cells and polychromasia were also reported (Fig. 2 A-B).

Table 1. Mean values and standard deviation of the haematological characteristics of infected and uninfected Leporinus macrocephalus in São Paulo State, Brazil

\begin{tabular}{lcccc}
\hline Characteristic & Uninfected $(\mathrm{n}=6)$ & Infected $(\mathrm{n}=15)$ & $\mathrm{CV}$ & $F$ test \\
\hline Erythrocyte $\left(10^{6} / \mu \mathrm{l}\right)$ & $1,772 \pm 0.48$ & $1,217 \pm 1.07$ & 5.54 & $3.31^{\mathrm{NS}}$ \\
Haemoglobin $(\mathrm{g} / \mathrm{dl})$ & $7.6 \pm 1.1$ & $4.6 \pm 4.8$ & 70.2 & $2.29^{\mathrm{NS}}$ \\
Hematocrit $(\%)$ & $29.7 \pm 6.8$ & $14.4 \pm 13.2$ & 58.3 & $6.85^{*}$ \\
MCV $(\mathrm{fl})$ & $177.6 \pm 40.7$ & $112.9 \pm 28.8$ & 24.5 & $14.71^{* *}$ \\
MCHC $(\mathrm{g} / \mathrm{dl})$ & $26.2 \pm 2.7$ & $19.6 \pm 5.7$ & 17.2 & $1.89^{* *}$ \\
Leukocyte $(\mu \mathrm{l})$ & $4,875.0 \pm 936.9$ & $4,313.6 \pm 4987.3$ & 26.6 & $2.25^{\mathrm{NS}}$ \\
Thrombocyte $(\%)$ & $55.3 \pm 16.9$ & $49.7 \pm 25.7$ & 40.0 & $0.53^{\mathrm{NS}}$ \\
Lymphocyte $(\%)$ & $29.4 \pm 15.9$ & $12.2 \pm 5.6$ & 58.4 & $14.74^{* *}$ \\
Neutrophil $(\%)$ & $11.2 \pm 4.6$ & $27.2 \pm 19.4$ & 43.1 & $6.11^{*}$ \\
Monocyte $(\%)$ & $8.7 \pm 2.3$ & $14.7 \pm 6.1$ & 64.5 & $4.39^{\mathrm{NS}}$ \\
Eosinophil $(\%)$ & $3.7 \pm 1.2$ & $13.3 \pm 5.1$ & $9.23^{*}$ \\
\hline
\end{tabular}

MCV: mean corpuscular volume; MCHC: mean corpuscular volume concentration; NS: not significant; * significant $(\mathrm{P}<0.05)$, ** significant $(\mathrm{P}<0.01)$. 

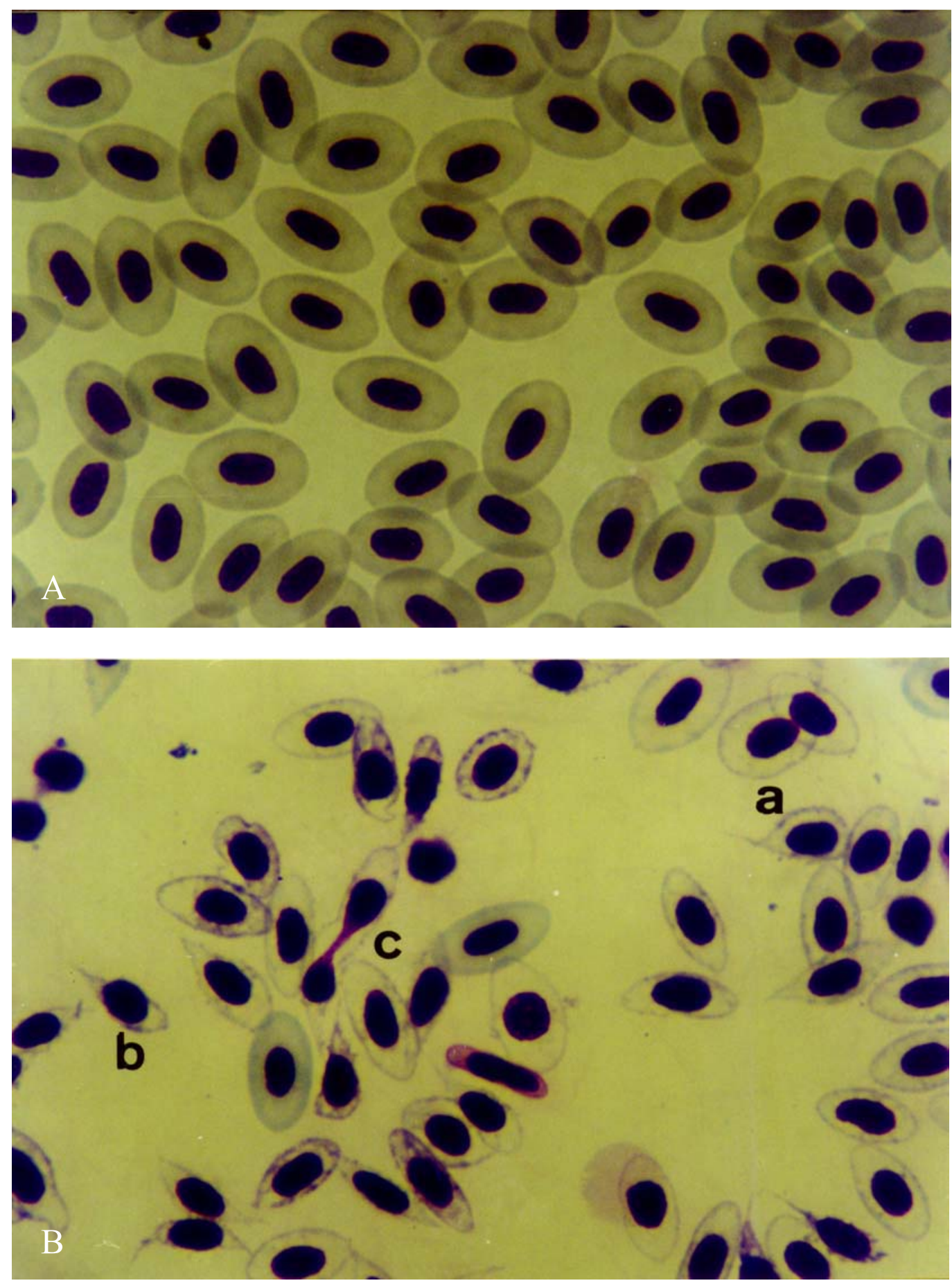

Figure 2. Blood smears of Leporinus macrocephalus. A - erythrocytes from uninfected fish; B erythrocytes from fish infected with Goezia leporini: a - different sizes of erythrocytes; b - erythrocytes presenting varied shape; $\mathrm{c}$ - cells in the division stage and polycromasia. Rosenfeld, $\mathrm{x}$ 2,275. 


\section{DISCUSSION}

Important observations can be made through diagnosis and pathological condition of fish (Pravda, 1998). Several studies on Goezia genus were conducted but most of them were based on parasite description. The lowest parasite prevalences were reported in Pseudoplatystoma corruscans infected with $8.3 \%$ G. spinulosa (Hamann, 1984), in Mastacembelus armatus infected with $0.09 \%$ G. moraveci (De and Dey, $1992)$ and in Goezia larvae $(0.12 \%)$ from Rhamdia guatemalensis (Moravec et al., 1995). In this study, the massive presence of nematodes had $65 \%$ prevalence, similar to that found by ElDarsh and Whitfield (1999) that reported up to $66.7 \%$ prevalence. Here, the nematodes were found firmly fixed to the stomach wall and exists indication of their presence associated to feed and secondary lesions in the host as commented by Deardorff and Overstreet (1980). Great mortality in a freshwater population of Morone saxatilis was related to the presence of Goezia sp. (Gaines and Rogers, 1972).

In the present study, infected L. macrocephalus showed reduced hematocrit, $\mathrm{MCV}$ and $\mathrm{MCHC}$ values. This suggests the occurrence of a microcytic-hypocromic anemia. Similar results were described in carp infected with Bothriocephalus acheilognathi (Sopinska, 1985), while no difference in hematocrit values were seen in rainbow trout infested with Lepeophtheirus salmonis. Anemia was also associated to Heteropneustes fossilis infected with metacercariae (Murad and Mustafa, 1988) and carp infected with Myxobolus artus (Yokoyama et al., 1996). No changes in erythrocytic results were observed in parasitized C. carpio (Kurovskaya and Osadchaya, 1993), M. platanus (Ranzani-Paiva et al., 1997), $P$. mesopotamicus and L. macrocephalus (TavaresDias et al., 1999b). The present observations on the hematocrit values were in accordance to Kelly et al. (2000) who have reported significant reduction in eels infected with Anguillicola crassus. Schuwerack et al. (2001) related decreased neutrophil, thrombocyte and lymphocyte percentages in lymphoid organs of carp infected with Sanguinicola inermis.

In the present study, Goezia infection was found to cause lymphocytopenia, neutrophilia and eosinophilia, similarly to reports in carp (Sopinska, 1985) and O. niloticus (Tavares-Dias et al., 2002). Although lymphocytosis, neutrophilia, monocytosis and eosinophilia were observed by Murad and Mustafa (1988) in $H$. fossilis. Silva-Souza et al. (2000) have reported increased neutrophyl percentage in Schizodon intermedius parasitized by $L$. cyprinacea. Moreover, these results differ from those obtained by Tavares-Dias et al. (1999b) in $P$. mesopotamicus and L. macrocephalus infected by Monogenoidea, I. multifiliis, Trichodina sp., $P$. pillulare and L. cyprinacea.

Microscopic studies of erythrocytes from $L$. macrocephalus parasitized with Goezia sp. demonstrated anisocytosis and poikilocytosis, similar to that observed in Tautogolabrus adspersus (Hickey Jr., 1982) and carp (Sopinska, 1985). In the present study, hypochromasia was similar to that reported by Sopinska (1985) in carp. Cellular division is a process that occurs in young cells (Murad et al., 1993), when elongation of the nucleus and central constriction can be observed, but little alteration occurs in the shape of the cell. This nucleus elongation is responsible for cells of a "rustic" shape according to Houston (1997). Cells with these characteristics were observed in several teleost fish species of North America. This was also observed in the present study in $L$. macrocephalus. Additional work must be done with cultivated L. macrocephalus, which showed higher susceptibility to this type of nematode. Based on personal experience, this is specially true for fish from Mato Grosso do Sul State, which are more susceptible to endoparasitic helminths than those observed in the South East of Brazil.

It is possible that the small number of collected fish with 200 to $600 \mathrm{~g}$ body weight was responsible for the absence of correlation. Although glucose and cortisol were not measured in this study, the presence of this nematode and the haematological changes indicate the possible effect of stress on fish. Moreover, this work is the first report about haematological alterations values in Brazilian freshwater cultivated fish infected with anisakid nematodes. 


\section{ACKNOWLEDGEMENTS}

We are grateful to Dr. Áureo Evangelista Santana and Eugênio de Campos Filho (Veterinary Hospital, FCAV, Unesp, Jaboticabal, SP) for haematological analysis and to Paula Rezende for English review of the manuscript.

\section{REFERENCES}

BANZATO, D.A.; KRONKA, S.N. Experimentação agrícola. 3.ed. Jaboticabal, FUNEP, 1995. 247p

BUSH, A.O.; LAFFERTY, K.D.; LOTZ, J.M. et al. Parasitology meets ecology on its own terms: Margolis et al. revisited. J. Parasitol., v.83, p.575583, 1997.

COLLIER, H.B. The standardization of blood haemoglobin determinations. Can. Med. Assoc. $J .$, v.50, p.550-552, 1944.

DE, N.C.; DEY, J. A new species of the genus Goezia Zeder, 1800 (Nematoda: Anisakidae) from the fish, Mastacembelus armatus (Lacep.) from West Bengal, India. Syst. Parasitol., v.22, p.189-197, 1992.

DEARDORFF, T.I.; OVERSTREET, R.M. Taxonomy and biology of North American species of Goezia (Nematoda: Anisakidae) from fishes, including three new species. Proc. Helminthol. Soc. Washington, v.47, p.192-217, 1980.

EL-DARSH, H.E.M.; WHITFIELD, P.J. The parasite community infecting flounders, Platichthys flesus, in the tidal Thames. $J$. Helminthol., v.73, p.203-214, 1999.

GAINES Jr., J.L.; ROGERS, W.A. Fish mortalities associated with Goezia sp. (Nematoda: Ascarididae) in Central Florida. ANNUAL CONFERENCE OF SOUTHEAST ASSOCIATION GAME FISH COMMUNITY, 25., 1972. P.496-497.

GOLDENFARB, P.B.; BOWYER, F.P.; HALL, E. et al. Reproductibility in the hematology laboratory: the microhematocrit determination. Am. J. Clin. Pathol., v.56, p.35-39, 1971.

HAMANN, M.I. Nematodos parasitos de peces pimelodidos del rio Parana medio, Republica
Argentina (Pisces, Pimelodidae). Neotropica, v.30, p.55-62, 1984.

HICKEY Jr., C.R. Comparative hematology of wild and captive cunners. Trans. Am. Fish Soc., v.111, p.242-249, 1982.

HOUSTON, A.H. Review: Are the classical hematological variables acceptable indicators of fish health? Trans. Am. Fish Soc., v.126, p.879894, 1997.

KELLY, C.E.; KENNEDY, C.R.; BROWN, J.A. Physiological status of wild European eel (Anguilla anguilla) infected with the parasitic nematode, Anguillicola crassus. Parasitology, v.120, p.195-202, 2000.

KLESIUS P.; ROGERS W. Parasitism of catfish and other farm raised food fish. J. Am. Vet. Med. Assoc., v.207, p.1473-1478, 1995.

KUROSVSKAYA, L.N.; OSADCHAYA, S.A. The influence of Ichthyophthirius multifiliis on underyearling carp, Cyprinus carpio. J. Ichthyol., v.33, p.81-92, 1993.

MARTINS, M.L.; ONAKA, E.M.; MORAES, F.R. et al. Recent studies on parasitic infections of freshwater cultivated fish in the State of São Paulo, Brazil. Acta Scient., v.24, p.981-985, 2002.

MARTINS, M.L.; YOSHITOSHI, E.R. A new nematode species Goezia leporini n. $\mathrm{sp}$. (Ascaridoidea) from cultivated freshwater fish Leporinus macrocephalus (Anostomidae) in Brazil. Braz. J. Biol., v.63, p.497-506, 2003.

MORAVEC, F.; VIVAS-RODRIGUEZ, C.; SCHOLZ, T. et al. Nematodes parasitic in fishes of cenotes (=sinkholes) of the Peninsula of Yucatán. Part 2. Larvae. Folia Parasitol., v.42, p.199-210, 1995.

MURAD, A.; EVERILL, S.P.; HOUSTON, A.H. Division of goldfish erythrocytes in circulation. Can. J. Zool., v.71, p.2190-2198, 1993.

MURAD, A.; MUSTAFA, S. Blood parameters of catfish, Heteropneustes fossilis (Bloch), parasitized by metacercariae of Diplostomulum sp. J. Fish Dis., v.11, p.365-368, 1988.

PRAVDA, D. The present european ichthyohaematology and prospects towards the $21^{\text {st }}$ century. Acta Vet. Brno, v.67, p.205-206, 1998 . 
RANZANI-PAIVA, M.J.; ISHIKAWA, C.M.; CAMPOS, B.E.S. et al. Haematological characteristics associated with parasitism in mullets, Mugil platanus Günther, from the estuarine region of Cananéia, São Paulo, Brazil. Rev. Bras. Zool., v.14, p.329-339, 1997.

RANZANI-PAIVA, M.J.; ISHIKAWA, C.M.; PORTELLA, M.C. et al. Hematologia da carpa comum Cyprinus carpio, infestada por Argulus sp. e após um tratamento com fosfato de 0,0dimetil-oxi-2,2,2,-tricloroetilo (Neguvon). Bol. Inst. Pesca, v.14, p.83-92, 1987.

ROSENFELD, G. Corante pancrômico para hematologia e citologia clínica. Nova combinação dos componentes do May-Grunwald e do Giemsa num só corante de emprego rápido. Mem. Inst. Butantan, v.20, p.329-334, 1947.

SCHUWERACK, P.M.M.; LEWIS, J.W.; HOOLE, D. et al. Ammonia-induced cellular and immunological changes in juvenile Cyprinus carpio infected with the blood fluke Sanguinicola inermis. Parasitology, v.122, p.339-345, 2001.

SILVA-SOUZA, A.T.; ALMEIDA, S.C.; MACHADO, P.M. Effect of the infestation by Lernaea cyprinacea Linnaeus, 1758 (Copepoda, Lernaeidae) on the leucocytes of Schizodon intermedius Garavello \& Britski, 1990 (Osteichthyes, Anostomidae). Braz. J. Biol., v.60, p.217-220, 2000.

SOPINSKA, A. Effects physiological factors, stress, and disease on hematologic paramerters of carp, with a particular reference to the leukocyte patterns.III. Changes in blood accompanyng branchionecrosis and bothriocephalosis. Acta Ichthyol. Pisc., v.15, p.141-165, 1985.
TAVARES-DIAS, M.; MARTINS, M.L.; KRONKA, S.N. Evaluation of the haematological parameters in Piaractus mesopotamicus Holmberg (Osteichthyes: Characidae) with Argulus sp (Crustacea, Branchiura) infestation and treatment with organophosphate. Rev. Bras. Zool., v.16, p.553555, 1999a.

TAVARES-DIAS, M.; MORAES, F.R.; MARTINS, M.L. et al. Haematological changes in Oreochromis niloticus (Osteichthyes: Cichlidae) with gill ichthyophthiriasis and saprolegniosis. Bol. Inst. Pesca, v.28, p.1-9, 2002.

TAVARES-DIAS, M.; SCHALCH, S.H.C.; MARTINS, M.L. et al. Hematologia de teleósteos brasileiros com infecção parasitária. I. Varáveis do Leporinus macrocephalus Garavello \& Britski, 1988 (Anostomidae) e Piaractus mesopotamicus Holmberg, 1887 (Characidae). Acta Scient., v.21, p.337-342, 1999b.

WINTROBE, M.M. Variations on the size and hemoglobin content of erythrocytes in the blood various vertebrates. Folia Haematol., v.51, p.3249, 1934

YOKOYAMA, H.; DANJO, T.; OGAWA, K. et al. Hemorrhagic anemia of carp associated with spore discharge of Myxobolus artus (Myxozoa: Myxosporea). Fish Pathol., v.31, p.19-23, 1996.

ZANIBONI FILHO, E. O desenvolvimento da piscicultura brasileira sem a deterioração da qualidade de água. Braz. J. Biol., v.57, p.3-9, 1997. 